\title{
WSPARCIE ADMINISTRACJI SAMORZĄDOWEJ W RAMACH PROJEKTÓW DOFINANSOWANYCH ZE ŚRODKÓW UNII EUROPEJSKIEJ
}

\begin{abstract}
Głównym celem pracy jest charakterystyka udzielonego wsparcia administracji samorządowej w ramach projektów dofinansowanych ze środków Unii Europejskiej (UE) z Programu Operacyjnego Kapitał Ludzki (POKL) w ramach Europejskiego Funduszu Społecznego (EFS). We wprowadzeniu podkreślono rolę ustawicznego kształcenia w rozwoju pracowników z punktu widzenia diagnozy problemów kadrowych polskiej administracji samorządowej. Przedstawiono możliwości, jakie w tym zakresie stworzyły dofinansowywane ze środków Unii Europejskiej programy operacyjne w perspektywie lat 2007-2013. Następnie, korzystając z wyników diagnozy społeczno-ekonomicznej polskiej administracji wyszczególniono problemy instytucjonalne i kadrowe występujące $w$ jednostkach samorządu terytorialnego (JST). W efekcie analizy dokumentów programowych POKL wskazano na możliwości uzyskania wsparcia przez samorządy ze środków UE. W dalszej części zaprezentowano przykłady zrealizowanych projektów samorządowych w jednym z powiatów województwa kujawsko-pomorskiego w trzech okresach badawczych oraz przedstawiono zakres wdrożeń i szkoleń skierowanych do 7 samorządów i ich 300 pracowników objętych dedykowanym procesem kształcenia. W szczególności omówiono specyfikę szkoleń, tj. zakres tematyczny, sposób organizacji oraz zastosowane metody, środki i narzędzia dydaktyczne. W ostatnim punkcie przedstawiono wyniki badań ewaluacyjnych przeprowadzonych wśród 300 pracowników (uczestników szkoleń) z punktu widzenia podniesienia kompetencji kadr, rozwoju ich kariery zawodowej oraz przydatności na stanowiskach pracy. Szczegółowe pytania dotyczyły zebrania opinii o przydatności realizowanych zagadnień, liczby godzin, sposobu organizacji oraz oceny zastosowanych metod, środków i narzędzi dydaktycznych. W zakończeniu omówiono korzyści, jakie odniosły polskie samorządy dzięki realizacji wdrożeń oraz dedykowanych szkoleń w ramach projektów dofinansowanych ze środków UE oraz zaprezentowano wnioski i rekomendacje dla potrzeb kontynuowania procesu kształcenia pracowników samorządowych.
\end{abstract}

Słowa kluczowe: pracownik samorządowy, jednostka samorządu terytorialnego, szkolenia, Unia Europejska, ocena szkoleń, rozwój osobisty, kariera zawodowa, stanowisko pracy.

\section{WPROWADZENIE}

Administracja samorządowa odpowiada za bezpieczeństwo i funkcjonowanie infrastruktury społecznej oraz musi spełnić rosnące oczekiwania obywateli, zarówno mieszkańców, jak i przedsiębiorców. Istotne jest zatem należyte przygotowanie pracowników admi-

1 Dr Monika Klemke-Pitek, Uniwersytet Technologiczno-Przyrodniczy, Wydział Zarządzania, ul. Kaliskiego 7, 85-796 Bydgoszcz, autor korespondencyjny: e-mail: monika.kp@utp.edu.pl; tel. +48501365005 
nistracji samorządowej do prawidłowego wykonywania zadań publicznych na stanowisku pracy $^{2}$. Jest to możliwe dzięki procesowi sukcesywnych szkoleń i doskonalenia pracowników samorządowych w celu zwiększenia ich sprawności działania na stanowisku pracy ${ }^{3}$.

W ciągu ostatnich kilku lat w Polsce zauważa się wzrost zainteresowania kształceniem kadr administracji publicznej, w tym administracji samorządowej. Jest to związane z możliwościami kształcenia pracowników samorządowych ze środków Unii Europejskiej (UE), w tym w szczególności Programu Operacyjnego Kapitał Ludzki (POKL) ${ }^{4}$.

POKL jest jednym z programów operacyjnych, który wspierał politykę społeczną i finansował działania Polski w dwóch płaszczyznach: przeciwdziałania bezrobociu oraz rozwoju zasobów ludzkich w latach 2007-2013. Program zawiera dziewięć osi priorytetowych, realizowanych równolegle na poziomie centralnym i regionalnym, w tym Priorytet V Dobre Rządzenie dedykowany administracji publicznej ${ }^{5}$.

Wykazane w części diagnostycznej POKL problemy polskiej administracji, wskazują na konieczność skoncentrowania wsparcia na priorytetowych wyzwaniach podniesienia potencjału administracyjnego polskiej administracji, jakim są: wzmocnienie zdolności do tworzenia wysokiej jakości prawa, opracowywania długofalowego programów i strategii oraz wzrostu jakości usług publicznych ${ }^{6}$.

W procesie pozyskiwania środków dla administracji samorządowej istotne jest przeprowadzenie właściwej diagnozy, adekwatnej do problemów kadrowych i instytucjonalnych administracji samorządowej. Obecnie uważa się, że jakość i zarządzanie jakością w administracji publicznej odgrywają istotną rolę w procesie absorpcji środków pochodzących z funduszy unijnych ${ }^{7}$. Przy realizacji projektów, samorządy muszą w większym zakresie wykorzystywać wiedzę zawartą w bliższym i dalszym otoczeniu oraz zawartą w całych jej zasobach wewnętrznych ${ }^{8}$

W celu zapewnienia wysokiej efektywności procesu doskonalenia kadr - kluczowym elementem jest zaplanowanie działaniach projektowych odpowiedniej organizacji szkoleń oraz dostosowanie metodyki nauczania do specyfiki kształcenia osób dorosłych (cykl Kolba $)^{9}$. Równocześnie zasadne jest przeprowadzanie ewaluacji, czyli oceny przydatności i skuteczności zrealizowanych działań szkoleniowych dla potrzeb permanentnego doskonalenia procesu kształcenia ustawicznego pracowników samorządowych ${ }^{10}$.

2 K. Tkacz-Krupa, Praktyka doskonalenia kadr administracji samorzadowej w województwie opolskim - wyniki badań, „Barometr Regionalny” 4/26 (2011), s. 85.

3 T. Listwan (red), Zarzadzanie kadrami. Studia ekonomiczne, Warszawa 2006.

4 Zob. szerzej: E. Kornberger-Sokołowska (red), R. Cieślak, J. Zdanukiewicz, Jednostki samorzadu terytorialnego jako beneficjenci środków europejskich, Warszawa 2012.

5 Program Operacyjny Kapitat Ludzki. Narodowe Strategiczne Ramy Odniesienia 2007-2013. Ministerstwo Infrastruktury i Rozwoju, Warszawa, 2015, s. 185-201.

6 Tamże.

7 A. Wojtach, Uwarunkowania zdolności absorpcyjnej funduszy unijnych w administracji publicznej, ,Zarządzanie i Finanse” 3/1, 2012.

8 M. Bugdol, Zarzadzanie jakościa w urzędach administracji publicznej. Teoria i praktyka, Warszawa 2008, s. 139.

9 I. Kaźmierska, I. Lachowicz, L. Piotrowska, Uczenie się dorostych - CYKL KOLBA, Ośrodek Rozwoju Edukacji, Warszawa 2014, s. 1-10.

${ }^{10}$ T. Grzeszczak, Modelowanie ewaluacji projektów europejskich, Warszawa 2011. 


\section{2. ŚRODKI UNII EUROPEJSKIEJ DEDYKOWANE ADMINISTRACJI SA- MORZĄDOWEJ}

Szansą na budowę sprawnej i skutecznej administracji publicznej wszystkich szczebli upatruje się w środkach finansowych PO KL, którego jedna z dziesięciu osi priorytetowych (priorytet V Dobre Rządzenie, działanie 5.2.) dedykowana została administracji samorządowej. Celem głównym Priorytetu V POKL, działanie 5.2. Wzmocnienie potencjału administracji samorządowej jest: Wzrost jakości usług publicznych świadczonych przez urzędy na szczeblu samorządu terytorialnego oraz poprawa jakości polityk i programów o zasięgu regionalnym i lokalnym ${ }^{11}$. Szczegółowe informacje prezentuje tabela 1.

Tabela 1. Podstawowe informacje o Priorytecie V Dobre Rządzenie działanie 5.2 na lata 20107-2013

\begin{tabular}{|c|c|c|}
\hline Lp. & $\begin{array}{c}\text { Nazwa } \\
\text { programu } \\
\text { operacyjnego }\end{array}$ & Program Operacyjny Kapitał Ludzki \\
\hline 1 & $\begin{array}{l}\text { Nazwa i nr prio- } \\
\text { rytetu }\end{array}$ & Priorytet V Dobre Rządzenie \\
\hline 2 & Nazwa funduszu & Europejski Fundusz Społeczny \\
\hline 3 & $\begin{array}{l}\text { Instytucja Zarzą- } \\
\text { dzająca }\end{array}$ & Ministerstwo Rozwoju Regionalnego \\
\hline 4 & $\begin{array}{l}\text { Instytucja Pośred- } \\
\text { nicząca }\end{array}$ & Ministerstwo Administracji i Cyfryzacji \\
\hline 5 & $\begin{array}{l}\text { Numer i nazwa } \\
\text { działania }\end{array}$ & 5.2. Wzmocnienie potencjału administracji samorządowej \\
\hline 6 & Cel działania & $\begin{array}{l}\text { Wzrost jakości usług publicznych świadczonych przez urzędy na szcze- } \\
\text { blu samorządu terytorialnego oraz poprawa jakości polityk i programów } \\
\text { o zasięgu regionalnym i lokalnym. }\end{array}$ \\
\hline 7 & $\begin{array}{l}\text { Typy możliwych } \\
\text { operacji }\end{array}$ & $\begin{array}{l}\text { 1. projekty ukierunkowane na poprawę obsługi obywatela i moderniza- } \\
\text { cje zarządzania w administracji samorządowej obejmujące m.in.: } \\
\text { - podnoszenie jakości, zwiększenie dostępności usług publicznych } \\
\text { przez urzędy administracji samorządowej (a) } \\
\text { - wdrażanie uprawnień zarządczych w administracji publicznej na } \\
\text { poziomie całej organizacji w tym zakresie zarządzania jakością lub } \\
\text { oceny poziomu funkcjonowania i rozwoju urzędów i w wybranych } \\
\text { aspektach jej funkcjonowania komunikacja wewnętrzna obieg doku- } \\
\text { mentów, zarządzanie ryzykiem, planowanie strategiczne (b) } \\
\text { 2. projekty ukierunkowane na podnoszenie kompetencji kadr m.in. } \\
\text { przez: } \\
\text { - wzmacnianie działów kadrowo-szkoleniowych jako centrów zarzą- } \\
\text { dzania zasobami ludzkimi w urzędach samorządu terytorialnego } \\
\text { w tym m.in poprzez szkolenia w zakresie modelu i narzędzi zarzą- } \\
\text { dzania zasobami ludzkimi, dofinansowanie studiów podyplom- } \\
\text { wych w zakresie zarządzania kadrami, opracowanie modelu i narzę- } \\
\text { dzi zarządzania zasobami ludzkimi w samorządzie terytorialnym } \\
\text { w zakresie: rekrutacji wdrażania na stanowisku pracy, okresowej }\end{array}$ \\
\hline
\end{tabular}

${ }^{11}$ Szczegótowy Opis Programu Operacyjnego Kapitat Ludzki. Narodowa Strategia Spójności, Ministerstwo Infrastruktury i Rozwoju, Warszawa 2014, s. 150-166. 
Tabela 1 (cd.)

\begin{tabular}{|c|c|c|}
\hline Lp. & $\begin{array}{c}\text { Nazwa } \\
\text { programu } \\
\text { operacyjnego }\end{array}$ & Program Operacyjny Kapitał Ludzki \\
\hline & & $\begin{array}{l}\text { oceny pracowniczej, rozwoju zawodowego i motywacyjnego sys- } \\
\text { temu wynagrodzeń (a), } \\
\text { - promowanie i wdrażanie zasad mechanizmów oraz procedur wzmac- } \\
\text { niających przejrzystość administracji oraz podnoszących poziom } \\
\text { kultury etycznej kadr administracji samorządowej (b), } \\
\text { - szkolenia ogólnie i specjalistyczne (stacjonarne i na odległość) dla } \\
\text { kadr urzędów zatrudnionych w administracji samorządowej (c), } \\
\text { - promowanie zasad i mechanizmów procedur wzmacniających przej- } \\
\text { rzystość w jednostkach samorządu terytorialnego, w szzególności } \\
\text { w formie sieci wymiany doświadczeń, kampanii informacyjno-pro- } \\
\text { mocyjnych, seminariów, konferencji i konkursów (d) } \\
\text { 3. projekty obejmujące wzmacnianie zdolności regulacyjnych i anali- } \\
\text { tycznych w tym m.in.: } \\
\text { - wzmacnianie zdolności jednostek samorządu terytorialnego w zakre- } \\
\text { sie stanowienia aktów prawa miejscowego oraz aktów administra- } \\
\text { cyjnych (a), } \\
\text { - wzmacnianie zdolności jednostek samorządu terytorialnego w zakre- } \\
\text { sie opracowywania, wdrażania i ewaluacji polityk i strategii o za- } \\
\text { sięgu regionalnym i lokalnym (b), } \\
\text { - wzmocnienie komórek w urzędach odpowiedzialnych za monitoro- } \\
\text { wanie i ewaluację polityk i strategii o zasięgu regionalnym lub lokal- } \\
\text { nym (c) } \\
\text { 4. wsparcie JST w zakresie wdrożenia standardów świadczenia e-usług } \\
\text { oraz elektronizacji wymiany korespondencji za pomocą ePUAP, } \\
\text { w tym m.in. poprzez wdrożenia dziedzinowych systemów informa- } \\
\text { tycznych, podniesienie kwalifikacji pracowników samorządowych, } \\
\text { działania informacyjne podnoszące stopień wykorzystania e-usług }\end{array}$ \\
\hline 8 & $\begin{array}{l}\text { Alokacja finan- } \\
\text { sowa na działanie } \\
\text { [EUR] }\end{array}$ & 199609967 \\
\hline
\end{tabular}

Źródło: Szczegółowy Opis Programu Operacyjnego...

W ramach działania zaplanowano wiele wskaźników monitorujących efektywność szkoleń dla pracowników, tj. ${ }^{12}$ :

- liczba pracowników JST, którzy ukończyli udział w szkoleniach z zakresu poprawy zdolności regulacyjnych - 23000 osób;

- liczba JST, których pracownicy ukończyli szkolenia z zakresu świadczenia elektronicznych usług publicznych - 800 jednostek;

- liczba JST, których pracownicy ukończyli szkolenia z zakresu monitorowania polityk publicznych w województwie -8 jednostek;

- liczba JST, których pracownicy ukończyli udział w szkoleniach z zakresu:

a) zarządzania satysfakcją klienta - 562 jednostki;

\footnotetext{
12 Tamże.
} 
b) zarządzania jakością - 843 jednostki;

c) zarządzania zasobami ludzkimi - 1124 jednostki;

d) poprawy dostępu do administracji publicznej - 562 jednostki.

\section{PRZYKLADY ZREALIZOWANYCH PROJEKTÓW SZKOLENIOWO- -WDROŻENIOWYCH DLA ADMINISTRACJI SAMORZĄDOWEJ}

Na podstawie przedstawionej diagnozy w Programie Operacyjnym Kapitał Ludzki oraz alokacji i typach możliwych operacji określonych w Szczegółowym Opisie Osi Priorytetowych POKL - Instytucja Pośrednicząca rokrocznie zatwierdza roczne plany działania na lata programowania dla Priorytetu V oraz cyklicznie ogłasza konkursy z poddziałania 5.2.1 Modernizacja zarządzania $w$ administracji samorządowej dedykowane JST.

W odpowiedzi samorządy przygotowują wnioski o dofinansowanie, w których planują i budżetują działania szkoleniowo-wdrożeniowe skierowane dla swoich jednostek. W tabeli 2 przedstawiono przykłady trzech zrealizowanych projektów skierowanych do 7 JST i ich pracowników w województwie kujawsko-pomorskim w latach 2007-2013. W szczególności wskazano na zróżnicowane podejście do organizacji procesu kształcenia: tj. wyboru miejsca szkoleń, liczby godzin szkoleniowych w module, liczby dni szkoleń w miesiącu oraz zakresu tematycznego modułów.

Tabela 2. Przykłady zrealizowanych projektów szkoleniowo-wdrożeniowych dofinansowanych z UE

\begin{tabular}{|c|c|c|c|}
\hline Projekt numer & 1 & 2 & 3 \\
\hline $\begin{array}{l}\text { JST objęte pro- } \\
\text { jektem }\end{array}$ & \multicolumn{3}{|c|}{$\begin{array}{c}\text { Gmina Barcin, Gmina Gąsawa, Gmina Janowiec Wielkopolski, Gmina } \\
\text { Łabiszyn, Gmina Rogowo, Gmina Żnin, Powiat Żniński }\end{array}$} \\
\hline Tytuł projektu & $\begin{array}{l}\text { Europejskie } \\
\text { Kompetencje } \\
\text { Urzędnika }\end{array}$ & $\begin{array}{c}\text { Profesjonalne Kadry - } \\
\text { Sprawne Urzędy Powiatu } \\
\text { Żnińskiego }\end{array}$ & $\begin{array}{l}\text { Urzędy Powiatu Żniń- } \\
\text { skiego - gotowe na } \\
\text { świadczenie elektronicz- } \\
\text { nych usług publicznych } \\
\text { dla mieszkańców }\end{array}$ \\
\hline Nr konkursu & 1/POKL/5.2.1/2008 & 2/POKL/5.2.1/2009 & 2/POKL/5.2.1/2013 \\
\hline $\begin{array}{l}\text { Okres realizacji } \\
\text { projektu }\end{array}$ & $01.07 .2008-30.06 .2010$ & $01.07 .2010-30.06 .2012$ & $01.01 .2014-30.06 .2015$ \\
\hline $\begin{array}{l}\text { Wartość pro- } \\
\text { jektu [PLN] }\end{array}$ & 887744,24 & 1227001,98 & 1906214,65 \\
\hline Liczba osób & 150 & 152 & 278 \\
\hline $\begin{array}{l}\text { Wartość pro- } \\
\text { jektu na osobę } \\
{[\mathrm{PLN}]}\end{array}$ & 5918,29 & 8072,38 & 6856,89 \\
\hline $\begin{array}{l}\text { Problem } \\
\text { główny }\end{array}$ & $\begin{array}{l}\text { Niewystarczająca spraw- } \\
\text { ność działania admini- } \\
\text { stracji samorządowej } \\
\text { szczebla gminnego i po- } \\
\text { wiatowego ze względu } \\
\text { na niskie kompetencje } \\
\text { urzędników. }\end{array}$ & $\begin{array}{l}\text { Niska sprawność funk- } \\
\text { cjonowania urzędów } \\
\text { gmin wiejskich i miej- } \\
\text { sko-wiejskich w aspekcie } \\
\text { świadczonych usług pu- } \\
\text { blicznych oraz niewystar- } \\
\text { czające kompetencje } \\
\text { urzędników. }\end{array}$ & $\begin{array}{l}\text { Niski standard świad- } \\
\text { czenia e-usług oraz nie- } \\
\text { wystarczający poziom } \\
\text { elektronizacji w tym } \\
\text { wymiany koresponden- } \\
\text { cji za pomocą plat- } \\
\text { formy ePUAP. }\end{array}$ \\
\hline
\end{tabular}




\begin{tabular}{|c|c|c|c|}
\hline Projekt numer & 1 & 2 & 3 \\
\hline Cel główny & $\begin{array}{l}\text { Wzrost sprawności } \\
\text { działania administracji } \\
\text { samorządowej szczebla } \\
\text { gminnego i powiato- } \\
\text { wego poprzez podnie- } \\
\text { sienie kompetencji } \\
\text { urzędników w ramach } \\
\text { szkoleń. }\end{array}$ & $\begin{array}{l}\text { Podniesienie sprawności } \\
\text { funkcjonowania urzędów } \\
\text { w aspekcie świadczonych } \\
\text { usług publicznych oraz } \\
\text { podwyższenie kompeten- } \\
\text { cji urzędników. }\end{array}$ & $\begin{array}{l}\text { Podwyższenie stan- } \\
\text { dardu świadczenia e- } \\
\text { usług oraz podniesienie } \\
\text { poziomu elektronizacji, } \\
\text { w tym wymiany kore- } \\
\text { spondencji za pomocą } \\
\text { platformy ePUAP. }\end{array}$ \\
\hline $\begin{array}{l}\text { Zadania } \\
\text { wdrożeniowe } \\
\text { w projekcie }\end{array}$ & brak wdrożeń & $\begin{array}{l}3 \text { wdrożenia: } \\
\text { 1) system monitorowania } \\
\text { poziomu satysfakcji klien- } \\
\text { tów z jakości usług pu- } \\
\text { blicznych; } \\
\text { 2) system kompetencji } \\
\text { kadr w JST oparty na ba- } \\
\text { daniu luk kompetencyj- } \\
\text { nych i potrzeb szkolenio- } \\
\text { wych urzędników na pod- } \\
\text { stawie zaktualizowanych } \\
\text { opisów stanowisk pracy; } \\
\text { 3) procedura aktualizowa- } \\
\text { nia opisu usług świadczo- } \\
\text { nych w JST. }\end{array}$ & $\begin{array}{l}3 \text { wdrożenia: } \\
\text { 1) wystawienie nowych } \\
\text { e-usług świadczonych } \\
\text { przez JST na platfor- } \\
\text { mie ePUAP; } \\
\text { 2) uruchomienie w JST } \\
\text { punktów potwierdzania } \\
\text { Profilu Zaufanego; } \\
\text { 3) działania informa- } \\
\text { cyjno-promocyjne pod- } \\
\text { noszące stopień wyko- } \\
\text { rzystania e-usług wśród } \\
\text { mieszkańców. }\end{array}$ \\
\hline $\begin{array}{l}\text { Liczba } \\
\text { konferencji }\end{array}$ & 2 & 3 & 1 \\
\hline $\begin{array}{l}\text { Moduły } \\
\text { szkoleń [M] }\end{array}$ & $\begin{array}{l}\text { M1. Kadra kierownicza } \\
\text { (zarządzanie projektami, } \\
\text { zarządzanie jakością, } \\
\text { system ocen pracowni- } \\
\text { czych, zarządzanie ryzy- } \\
\text { kiem, techniki komuni- } \\
\text { kacji, zarządzanie cza- } \\
\text { sem, umiejętność działa- } \\
\text { nia pod presją, etyka } \\
\text { i wizerunek menedżera, } \\
\text { narzędzia informatyczne } \\
\text { w zarządzaniu). } \\
\text { M2. Urzędnicy zajmu- } \\
\text { jący się zarządzaniem } \\
\text { gruntami, nieruchomo- } \\
\text { ściami i mieniem komu- } \\
\text { nalnym (komunikacja } \\
\text { i obsługa klienta, zarzą- } \\
\text { dzanie czasem i archiwi- } \\
\text { zacja, dokumentów, stres } \\
\text { w pracy, postępowanie }\end{array}$ & $\begin{array}{l}\text { M1. Kadra kierownicza } \\
\text { (ustawa o ochronie infor- } \\
\text { macji niejawnych, zamó- } \\
\text { wienia publiczne, zarzą- } \\
\text { dzanie ryzykiem, metodyka } \\
\text { tworzenia prawa miejsco- } \\
\text { wego, kontrola zarządcza). } \\
\text { M2. Urzędnicy odpowie- } \\
\text { dzialni za przygotowanie } \\
\text { i rozliczanie projektów UE } \\
\text { (fundusze miękkie - EFS, } \\
\text { fundusze twarde - EFRR). } \\
\text { M3. Urzędnicy odpowie- } \\
\text { dzialni za rachunkowość } \\
\text { budżetową i finanse pu- } \\
\text { bliczne (ordynacja podat- } \\
\text { kowa, KPA i orzecznictwo, } \\
\text { zagadnienia prawne). } \\
\text { M4.Urzędnicy zajmujący } \\
\text { się bezpośrednio obsługą } \\
\text { klienta (standardy obsługi } \\
\text { klienta, komunikacja, stres, } \\
\text { asertywność). }\end{array}$ & $\begin{array}{l}\text { M1. Kadra kierownicza } \\
\text { (zarządzanie zmianą } \\
\text { w procesie świadczenia } \\
\text { e-usług, zagadnienia } \\
\text { prawne w świetle zmian } \\
\text { ustawy o informatyza- } \\
\text { cji, elektroniczny obieg } \\
\text { dokumentów, obsługa } \\
\text { platformy ePUAP. } \\
\text { M2. Urzędnicy (narzę- } \\
\text { dzia informatyczne } \\
\text { w pracy urzędnika; za- } \\
\text { gadnienia prawne } \\
\text { w świetle zmian ustawy } \\
\text { o informatyzacji, elek- } \\
\text { troniczny obieg doku- } \\
\text { mentów, obsługa plat- } \\
\text { formy ePUAP. }\end{array}$ \\
\hline
\end{tabular}




\begin{tabular}{|c|c|c|c|}
\hline Projekt numer & 1 & 2 & 3 \\
\hline & $\begin{array}{l}\text { administracyjne zamó- } \\
\text { wienia publiczne, gospo- } \\
\text { darka gruntami i nieru- } \\
\text { chomościami, prawo bu- } \\
\text { dowlane, planowanie } \\
\text { i realizacja inwestycji } \\
\text { gminnych, narzędzia in- } \\
\text { formatyczne w pracy } \\
\text { urzędnika. } \\
\text { M3. Urzędnicy odpowia- } \\
\text { dający za gospodarkę } \\
\text { finansami, podatki i rea- } \\
\text { lizację budżetu (postępo- } \\
\text { wanie administracyjne, } \\
\text { zamówienia publiczne, } \\
\text { rachunkowość budże- } \\
\text { towa, podatki i opłaty lo- } \\
\text { kalne, finanse publiczne, } \\
\text { narzędzia informatyczne } \\
\text { w pracy urzędnika). } \\
\text { M4. Urzędnicy zajmują- } \\
\text { cy się promocją i rozwo- } \\
\text { jem lokalnym budżetu } \\
\text { (postępowanie admini- } \\
\text { stracyjne, zamówienia } \\
\text { publiczne, zasady two- } \\
\text { rzenia strategii i planów } \\
\text { rozwoju lokalnego, pro- } \\
\text { mocja gminy i powiatu, } \\
\text { Public Relations w urzę- } \\
\text { dzie, narzędzia informa- } \\
\text { tyczne w pracy urzęd- } \\
\text { nika). }\end{array}$ & $\begin{array}{l}\text { M5. Urzędnicy przygoto- } \\
\text { wujący decyzje administra- } \\
\text { cyjne z zakresu spraw po- } \\
\text { datkowych (przygotowanie } \\
\text { decyzji administracyjnych } \\
\text { pod względem formalnym } \\
\text { i merytorycznym). } \\
\text { M6. Urzędnicy przygoto- } \\
\text { wujący decyzje administra- } \\
\text { cyjne z zakresu spraw oby- } \\
\text { watelskich (przygotowanie } \\
\text { decyzji administracyjnych } \\
\text { pod względem formalnym } \\
\text { i merytorycznym). } \\
\text { M7. Urzędnicy przygoto- } \\
\text { wujący decyzje administra- } \\
\text { cyjne z zakresu spraw } \\
\text { zagospodarowania prze- } \\
\text { strzennego, budownictwa } \\
\text { i ochrony środowiska przy- } \\
\text { gotowanie decyzji admini- } \\
\text { stracyjnych pod względem } \\
\text { formalnym i merytorycz- } \\
\text { nym). } \\
\text { M8. Urzędnicy przygoto- } \\
\text { wujący decyzje administra- } \\
\text { cyjne z zakresu spraw go- } \\
\text { spodarki nieruchomościami } \\
\text { i drogownictwa (przygoto- } \\
\text { wanie decyzji administra- } \\
\text { cyjnych pod względem for- } \\
\text { malnym i merytorycznym). }\end{array}$ & $\begin{array}{l}\text { M3. Informatycy (do- } \\
\text { kument elektroniczny } \\
\text { i proces umieszczania } \\
\text { w CRWD; tworzenie } \\
\text { i modyfikacja formula- } \\
\text { rzy elektronicznych; } \\
\text { implementacja usług } \\
\text { i formularzy na platfor- } \\
\text { mie E-PUAP; bezpie- } \\
\text { czeństwo i utrzymanie } \\
\text { systemów informatycz- } \\
\text { nych). }\end{array}$ \\
\hline $\begin{array}{l}\text { Miejsce } \\
\text { szkoleń }\end{array}$ & $\begin{array}{l}\text { poza urzędem } \\
\text { (wyjazdowe) }\end{array}$ & $\begin{array}{l}\text { poza urzędem } \\
\text { (stacjonarne) }\end{array}$ & $\begin{array}{c}\text { w urzędzie } \\
\text { (stanowiskowe) }\end{array}$ \\
\hline $\begin{array}{l}\text { Liczba godzin } \\
\text { szkoleniowych } \\
\text { w module }\end{array}$ & $10 \mathrm{dni} \times 8 \mathrm{~h}=80 \mathrm{~h}$ & 8 dni $\times 8 h=64 h$ & $6 \mathrm{dni} \times 8 \mathrm{~h}=48 \mathrm{~h}$ \\
\hline $\begin{array}{l}\text { Liczba dni szko- } \\
\text { leń w miesiącu }\end{array}$ & $4 \mathrm{dni}$ & $2 \mathrm{dni}$ & 1 dzień \\
\hline $\begin{array}{l}\text { Metody } \\
\text { dydaktyczne }\end{array}$ & \multicolumn{3}{|c|}{ wykład, ćwiczenia, dyskusja, case study } \\
\hline $\begin{array}{l}\text { Środki i narzę- } \\
\text { dzia dydak- } \\
\text { tyczne }\end{array}$ & \multicolumn{3}{|c|}{$\begin{array}{l}\text { materiały drukowane, flipchart, prezentacja multimedialna, tablica interaktywna, } \\
\text { programy komputerowe }\end{array}$} \\
\hline
\end{tabular}

Źródło: opracowanie własne na podstawie przeprowadzonych badań ewaluacyjnych. 


\section{WYNIKI BADAŃ EWALUACYJNYCH PROJEKTÓW SZKOLENIOWO- -WDROŻENIOWYCH DLA ADMINISTRACJI SAMORZADOWEJ}

W niniejszej części przedstawiono wyniki badań ewaluacyjnych przeprowadzonych wśród 300 pracowników uczestniczących w szkoleniach w ramach trzech zrealizowanych projektów UE. Pracownicy dokonywali oceny szkoleń dla modułu, w którym uczestniczyli przy wykorzystaniu anonimowego kwestionariusza ankiety w skali 5-stopniowej (gdzie 5 oznacza ocenę najwyższą, a 1 ocenę najniższą). Uśrednione wyniki dla wszystkich projektów oraz indywidualnie dla każdego projektu zostały przedstawione na wykresach 1-4.

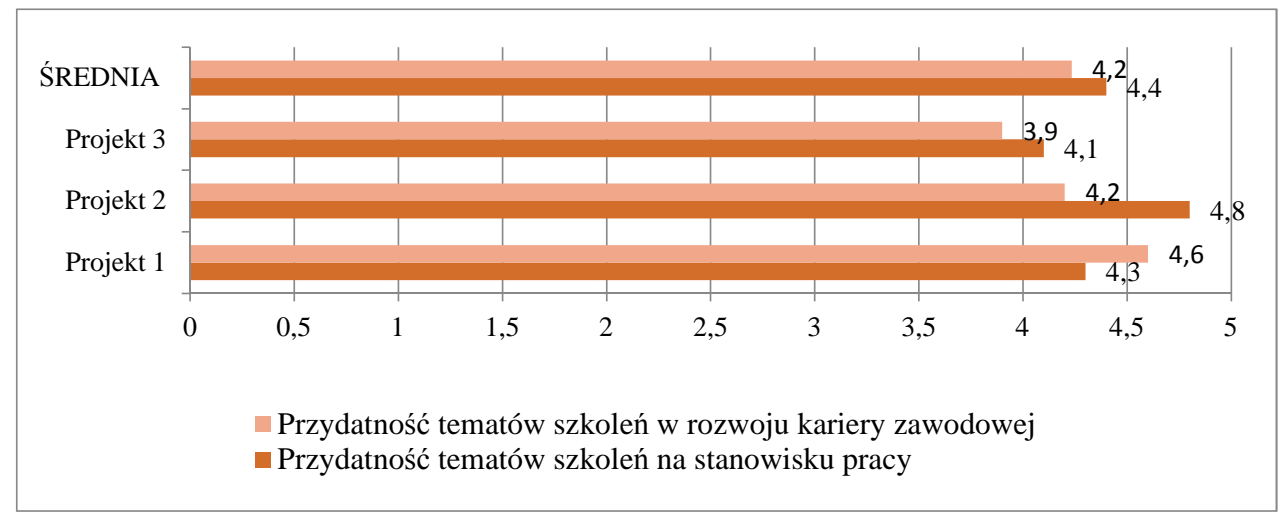

Wykres 1. Ocena przydatności tematów szkoleń na stanowisku pracy oraz w rozwoju kariery zawodowej pracowników

Źródło: opracowanie własne na podstawie przeprowadzonych badań ewaluacyjnych.

Średnia ocena przydatności tematów szkoleń na stanowisku pracy wyniosła 4,4, a w rozwoju kariery zawodowej nieco niżej $(4,2)$. Oceny były zróżnicowane dla projektów:

- przydatność tematyki szkoleń na stanowisku pracy - oceniono najwyżej $(4,8)$ w projekcie 2, a najniżej $(4,1)$ w projekcie 3 ;

- przydatność tematyki szkoleń dla potrzeb rozwoju kariery zawodowej pracowników - oceniono najwyżej $(4,6)$ w projekcie 1 , a najniżej $(3,9)$ w projekcie 3.

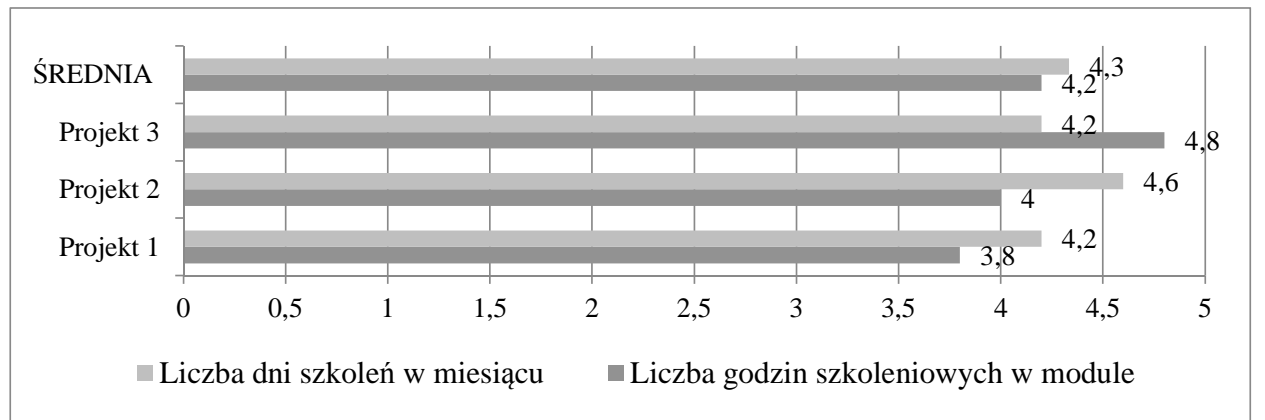

Wykres 2. Ocena procesu organizacji szkoleń: adekwatność liczby godzin szkoleniowych w module oraz zorganizowanych dni szkoleń w miesiącu

Źródło: opracowanie własne na podstawie przeprowadzonych badań ewaluacyjnych. 
Średnia ocena organizacji szkoleń tj. liczby godzin szkoleniowych w module wyniosła 4,2, a dni szkoleń w miesiącu nieco wyżej $(4,3)$. Oceny były zróżnicowane dla projektów:

- adekwatność liczby godzin szkoleniowych została oceniona najwyżej $(4,8)$ w projekcie 3 , a najniżej $(3,8)$ w projekcie 1 ;

- adekwatność liczby dni szkoleń w miesiącu została oceniona najwyżej $(4,6)$ w projekcie 2, a niżej $(4,2)$ w pozostałych projektach 1 i 3.

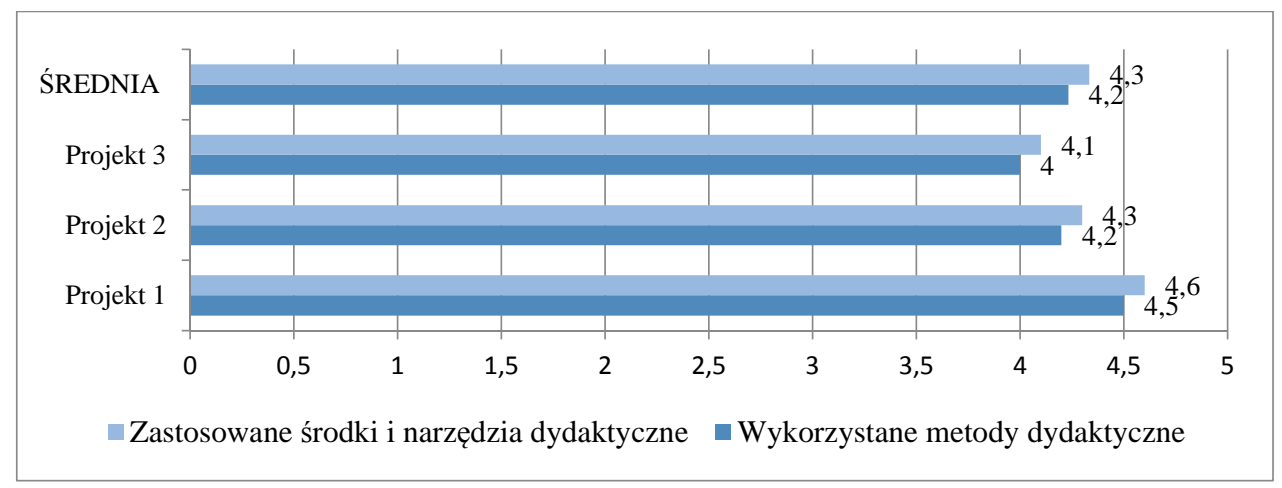

Wykres 3. Ocena wykorzystanych metod oraz zastosowanych środków i narzędzi dydaktycznych Źródło: opracowanie własne na podstawie przeprowadzonych badań ewaluacyjnych.

Średnia ocena wykorzystanych metod dydaktycznych wyniosła 4,2, a zastosowanych środków i narzędzi dydaktycznych nieco wyżej 4,3. Oceny metod oraz środków i narzędzi były zróżnicowane dla projektów:

- wykorzystane metody dydaktyczne zostały ocenione najwyżej $(4,5)$ w projekcie 1 , a najniżej $(4,0)$ w projekcie 3 ;

- zastosowane środki i narzędzia dydaktyczne zostały ocenione najwyżej $(4,6)$ w projekcie 1, a najniżej $(4,1)$ w projekcie 3 .

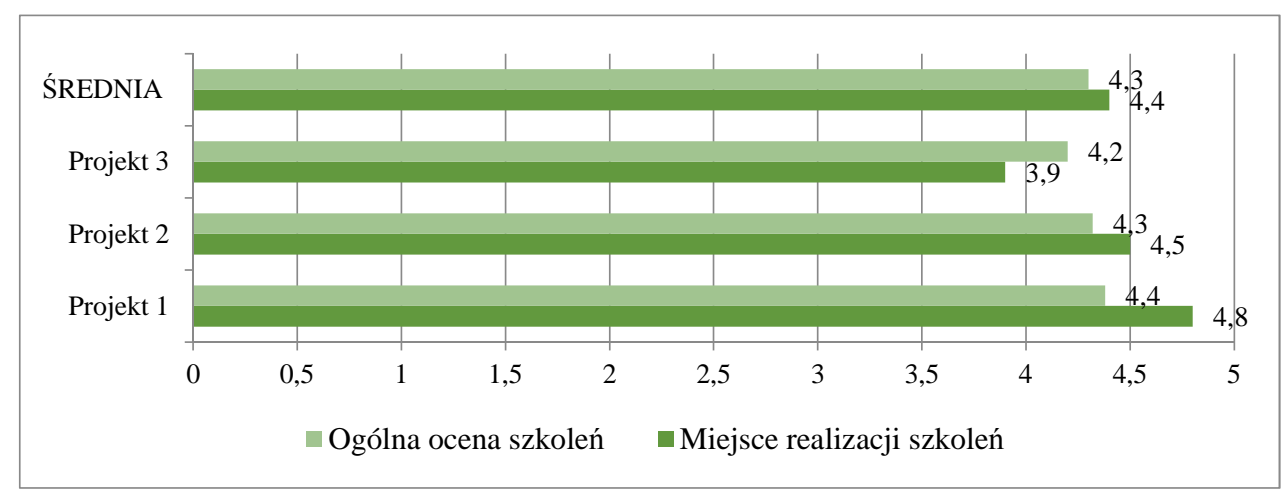

Wykres 4. Ocena miejsca organizacji szkoleń oraz ogólna ocena szkoleń

Źródło: opracowanie własne na podstawie przeprowadzonych badań ewaluacyjnych. 
Średnia ocena miejsca organizacji szkoleń wyniosła 4,4, natomiast ogólna ocena szkoleń ukształtowała się na poziomie nieco niższym $(4,3)$. Oceny były zróżnicowane dla projektów:

- miejsce szkoleń zostało ocenione najwyżej $(4,8)$ w projekcie 1 , a najniżej $(3,9)$ w projekcie 3;

- najwyższą ogólną ocenę szkoleń $(4,4)$ uzyskał projekt 1 , a najniższą $(4,2)$ projekt 3.

\section{PODSUMOWANIE}

Dotychczasowa realizacja działania 5.2 PO KL w znaczący sposób przyczyniła się do zmodernizowania polskiej administracji samorządowej. Wsparciem w ramach 400 różnorodnych projektów w latach 2007-2013 objęto ponad 50\% samorządów, czyli ok. 1400 JST. W efekcie zrealizowanych projektów szkoleniowo-wdrożeniowych uzyskano najważniejsze efekty i usprawnienia ${ }^{13}$ :

- System kompetencji kadr w 680 JST (24\%), w którym sporządzono kompetencyjne opisy stanowisk pracy, przeprowadzono pomiar kompetencji wśród pracowników, określono potrzeby szkoleniowe, co pozwoliło na dostosowanie polityki szkoleniowej do zdiagnozowanych potrzeb pracowników samorządowych.

- System monitorowania satysfakcji klientów w 615 JST (22\%), w którym opracowano wzory papierowych i elektronicznych ankiet do badania satysfakcji klienta oraz procedury monitorowania i poprawy jakości usług świadczonych przez JST, co wpłynęło pozytywnie zarządzanie jakością usług i wizerunek urzędów.

- Wspólna Metoda Samooceny CAF w 464 JST (17\%), w której opracowano raporty samooceny i raporty doskonalenia JST, co wpłynęło na poprawę funkcjonowania JST i usprawnienie przepływu komunikacji wewnętrznej wśród pracowników.

- System zarządzania ISO (norma 9001) w 328 JST (12\%), dzięki któremu przygotowano JST do wdrożenia systemu i przeprowadzenia audytu certyfikującego, co w efekcie poprawiło zarządzanie jakością usług w urzędach, w tym wizerunek urzędów.

- Uruchomienie nowych e-usług w 162 JST (6\%), czyli możliwości załatwiania spraw urzędowych przez Internet dzięki udostępnieniu usług urzędowych na platformie ePUAP i umożliwienie uzyskania przez mieszkańców „,profili zaufanych”, czyli bezpłatnych podpisów elektronicznych, którymi mogą się posługiwać w komunikacji online z urzędem.

Oprócz powyższych wdrożeń - wsparciem szkoleniowym objęto ponad 120 tysięcy pracowników samorządowych w zakresie podnoszenia wiedzy i kwalifikacji zawodowych. Na podstawie wyników badań ewaluacyjnych przeprowadzonego procesu szkoleń sformułowano następujące wnioski, które mogą stanowić rekomendacje dla potrzeb procesu kształcenia pracowników samorządowych w kolejnym okresie programowania 2014-2020:

- Optymalne szkolenia dla pracowników samorządowych powinny być organizowane w cyklach 6 dni x 8 godzin szkoleń w czasie pracy, stąd moduł szkoleniowy nie powinien przekraczać 48 godzin.

\footnotetext{
${ }^{13}$ Wsparcie administracji samorządowej w ramach Priorytetu V „Dobre Rządzenie” Programu Operacyjnego Kapitał Ludzki 2007-2013, Fundusze Europejskie w Polsce. Ministerstwo Administracji i Cyfryzacji, Warszawa 2014.
} 
- Miejsce szkoleń winno być zlokalizowane poza stanowiskiem pracy (w sali szkoleniowej); za najbardziej efektywne uznano 2-dniowe warsztaty wyjazdowe z noclegiem odbywające się 2 dni w miesiącu w grupie liczącej nie więcej niż 15 osób.

- Tematyka szkoleń w module powinna być zróżnicowana, stąd oprócz zagadnień specjalistycznych (szkoleń twardych) związanych z przekazywaniem wiedzy merytorycznej na stanowisku pracy - winny być poruszane zagadnienia ogólne (szkolenia miękkie) ukierunkowane na rozwijanie indywidualnych cech uczestników (komunikacja interpersonalna, asertywność, motywacja, radzenie sobie ze stresem, zarządzanie czasem, rozwiązywanie konfliktów w grupie).

- Metodyka zajęć powinna bazować na krótkim wprowadzeniu (wykładzie), następnie indywidualnych lub grupowych ćwiczeniach, przy wykorzystaniu case study i włączania uczestników do dyskusji oraz wymiany dobrych praktyk. W procesie szkoleń należy odwoływać się doświadczeń i wiedzy uczestników w zakresie faktycznych problemów na stanowisku pracy zgodnie z cyklem Kolba (doświadczenie - refleksja - generalizowanie - zastosowanie).

- Środki i narzędzia dydaktyczne muszą być zróżnicowane, uczestnicy powinni mieć możliwość pracy z tekstem, a trener powinien w jak najszerszym stopniu wykorzystywać urozmaicone środki przekazu (flipchart, prezentacja multimedialna, tablica interaktywna i programy komputerowe).

\section{LITERATURA}

[1] Bugdol M., Zarzadzanie jakościq w urzędach administracji publicznej. Teoria i praktyka, Wydawnictwo Difin Sp. z o.o., Warszawa 2008.

[2] Grzeszczak T. Modelowanie ewaluacji projektów europejskich, Wydawnictwo Placet, Warszawa 2011.

[3] Kaźmierska, I. Lachowicz, L. Piotrowska, Uczenie się dorostych - CYKL KOLBA, Ośrodek Rozwoju Edukacji, Warszawa 2014.

[4] Kornberger-Sokołowska E. (red), Cieślak R., Zdanukiewicz J., Jednostki samorzqdu terytorialnego jako beneficjenci środków europejskich, Wydawnictwo Wolters Kluwer Polska SA, Warszawa 2012.

[5] Listwan T. (red), Zarzadzanie kadrami. Studia ekonomiczne, Wydawnictwo C.H. Beck, Warszawa 2006.

[6] Program Operacyjny Kapitat Ludzki. Narodowe Strategiczne Ramy Odniesienia 2007-2013. Ministerstwo Infrastruktury i Rozwoju, Warszawa 2015.

[7] Szczegółowy Opis Programu Operacyjnego Kapitat Ludzki. Narodowa Strategia Spójności, Ministerstwo Infrastruktury i Rozwoju, Warszawa 2014.

[8] Tkacz-Krupa K., Praktyka doskonalenia kadr administracji samorządowej w województwie opolskim - wyniki badań, „Barometr Regionalny” 4/26 (2011)

[9] Wojtach A., Uwarunkowania zdolności absorpcyjnej funduszy unijnych $w$ administracji publicznej, ,Zarządzanie i Finanse” 3/1, 2012.

[10] Wsparcie administracji samorzadowej w ramach Priorytetu V „Dobre Rzadzenie” Programu Operacyjnego KAPITAE LUDZKI 2007-2013, Fundusze Europejskie w Polsce. Ministerstwo Administracji i Cyfryzacji, Warszawa 2014. 


\section{ASSISTANCE GRANTED TO LOCAL AUTHORITIES' ADMINISTRATION PERSONNEL AS A PART OF PROJECTS CO-FINANCED FROM THE EU FUNDS}

The primary objective of the paper has been to provide characteristics of the assistance granted to local authorities' administration personnel as part of projects co-financed from the EU funds, the Operational Programme Human Capital (OPHC) as part of the the European Social Fund (ESF). The introduction highlights the role of lifelong learning in personnel development in terms of Polish local authorities administration HR problems diagnosis. The possibilities offered by the 2007-2013 EU co-financed operational programmes are presented. Then, drawing on the results of the socioeconomic Polish administration personnel diagnosis, institution - and HR-related problems of the local authorities are specified. As a result of the Operational Programme Human Capital programme documents analysis, possibilities of local authorities to receive EU funds assistance are demonstrated. Further the paper provides the characteristics of the local authority projects executed in one of the counties of the Kujawsko-Pomorskie Province in 3 research periods and demonstrates the scope of implementations and trainings for 7 local authorities and their 300 employees covered by dedicated lifelong learning; especially a specific nature of the trainings; the range of the topics, organization method and the teaching methods, means and tools applied. Finally, the article presents the research of evaluation studies which involved 300 employees (training participants). The employees evaluated the trainings in terms of staff competence enhancement, professional career development and the training outcomes applicability for the job. Detailed questions concerned a collection of opinions on the applicability of the issues covered, number of hours, organization methods and the evaluation of the teaching methods, means and tools applied. The conclusion discuses how Polish local authorities benefited from the implementations and dedicated trainings and demonstrates conclusions and recommendations for lifelong learning of local-authorities' personnel.

Keywords: local authorities' employee, local authority, trainings, the European Union, training evaluation, personal development, professional career, position.

DOI:10.7862/rz.2017.hss.26

Przestano do redakcji: luty $2017 \mathrm{r}$. Przyjęto do druku: czerwiec $2017 \mathrm{r}$. 